\title{
Agglomeration externalities and localized employment growth: the performance of industrial sites in Amsterdam
}

\author{
Friso de Vor • Henri L. F. de Groot
}

Received: 26 March 2008 / Accepted: 4 October 2008 / Published online: 13 November 2008

(C) The Author(s) 2008. This article is published with open access at Springerlink.com

\begin{abstract}
This paper addresses the question to what extent the performance of industrial sites is affected by their local economic structure and accessibility. For this aim, we test for the existence of statistically significant relationships between agglomeration externalities (specialization, diversity, and competition), accessibilty measures and the employment growth of a particular industry on a particular site. We use data on employment growth of site-industries on 68 formal industrial sites in the municipality of Amsterdam between 1998 and 2006. We show that at the site-industry level, specialization hampers growth. Furthermore, we find that industrial sites that are easily accessible from the highway grow relatively fast, as well as sites located in the Amsterdam harbour area.
\end{abstract}

JEL Classification $\quad \mathrm{C} 31 \cdot \mathrm{O} 18 \cdot \mathrm{R} 11$

\section{Introduction}

The planning of industrial sites has been subject to much debate in the Netherlands. In these public discussions most attention is devoted to the urgency of establishing new industrial sites, the location of these sites, and the extent to which these sites harm the environment and landscape. The lack of attention to the economic implications of these

F. de Vor

Department of Spatial Economics, VU University Amsterdam,

Amsterdam, The Netherlands

e-mail: fvor@feweb.vu.nl

H. L. F. de Groot $(\varangle)$

VU University Amsterdam and Tinbergen Institute, De Boelelaan 1105,

1081 HV Amsterdam, The Netherlands

e-mail: hgroot@feweb.vu.nl 
formal locations of economic activity is striking. How important are industrial sites for regional development and growth? Do sites provide unique circumstances vis-à-vis other (informal) locations of economic activity? These are questions that are central in the field of regional science. Spatial variables in particular, such as location, proximity and accessibility, traditionally play a crucial role in this field. This is stressed by the widespread belief that "space matters" (Krugman 1991). However, much debate within regional science occurs about the way space matters. Neoclassical regional growth theory tends to suggest that regional differences will disappear in the long run. This is in marked contrast to the New Economic Geography where agglomeration forces are said to result in geographical clustering and specialization patterns (Hoogstra and Van Dijk 2004).

In view of these relevant discussions for regional development, this study contributes to this debate by elaborating on the importance of (external) agglomeration economies and accessibilty for the economic performance of industrial sites. In this sense, our analysis is strongly influenced by the seminal contribution "Growth in Cities" of Glaeser et al. (1992), which provides a dynamic view ${ }^{1}$ on the formation and growth of cities. In accordance with this approach, we explain the performance of sites as a function of Marshall-Arrow-Romer (MAR), Jacobs and Porter externalities. By applying Glaeser et al.'s methodology on industrial sites, we obtain insight into whether local specialization, local diversity, or local competition of an economy is related to local economic growth processes on the aggregation level of industrial sites. Furthermore, we look into the spatial pattern of growth and especially consider the importance of accessibility as a growth-promoting factor. As such, the analysis may reveal useful lessons for development planners and land developers by pointing out some of the more critical factors that affect performance of industrial sites. Such lessons may be particularly useful in restructuring processes that many industrial sites are currently undergoing.

Our analysis is based on employment data of industrial sites in the municipality of Amsterdam. Being the capital of the Netherlands with a relatively heterogeneous production structure, Amsterdam forms a coherent urban system which is interesting to examine (Van der Vegt et al. 2006). ${ }^{2}$ Due to its open character, an essential asset of the Amsterdam urban system is its dynamics: new industries rise whereas other industries fall in terms of economic importance (O+S Amsterdam 2007). As such, our study complements existing ones that have been conducted following the seminal work by Glaeser et al. (1992) in that we look at a very low level of spatial aggregation. A review of the existing literature, by means of a meta-analysis, points out that, amongst other things, the level of spatial aggregation matters for the strength with which agglomeration forces are operational (De Groot et al. 2007). So far, the level of spatial aggregation of the industrial site has been neglected in testing the relationship

\footnotetext{
1 A dynamic view refers, instead of explaining the level of productivity at a certain point of time ('static view'), to explaining the changes in productivity, or growth, over a certain time period (Rosenthal and Strange 2004).

2 On a more pragmatic note, another reason for choosing this case-study can be found by the availability of data: the municipality of Amsterdam provided detailed employment data relating to the spatial level of aggregation of industrial sites.
} 
between agglomeration and growth. In the scarce available literature about industrial sites, aspects of restructuring or modernization of sites are typically emphasized. In this literature industrial sites are mainly considered from a planning or environmental point of view, thereby largely neglecting the economic perspective. Hence, by considering employment growth on the scale of industrial sites, located in the municipality of Amsterdam, we aim to get insight into the determinants of growth on the disaggregated spatial level of industrial sites.

The paper is organized as follows. The next section provides an overview of the conceptual arguments about the relationship between the proposed externalitiesMAR, Jacobs and Porter-and localized growth. Section 3 elaborates on the application of Glaeser et al. (1992) on the growth of industrial sites and gives a description of the data. In Sect. 4 we present relevant measures of performance and externalities. Section 5 sets out and discusses the estimation methods and accompanying results, and addresses the importance of specific elements of space (such as accessibility). Finally, Sect. 6 concludes.

\section{Literature review}

Cities provide a natural laboratory to study dynamic externalities as they facilitate communications between economic agents (Henderson 1997). If an industry is subject to MAR externalities, producers are likely to cluster together. They tend to primarily specialize in a particular activity, or they become closely interconnected to a set of related activities thereby fostering short-term economic growth (Henderson 2003). MAR (or localization) externalities are associated with a high local concentration of economic activity in a company's own industry. Benefits potentially accrue from three sources: labour market pooling, input-output linkages, and knowledge spillovers (cf. Marshall 1890). A high concentration of an industry can attract and sustain a large labour force with the skills demanded by that industry. This considerably lowers search costs and augments a firm's flexibility in hiring and laying off personnel. Input-output linkages refer to the fact that a concentration of an industry attracts both supplier firms and client firms to its region. Finally, knowledge is hypothesized to spill over from one firm to another without the donor firm giving its complete permission or receiving complete compensation. These spillovers can arise from job mobility or social activities between employees of different firms (Breschi and Lissoni 2003). Specialization enhances full exploitation of scale externalities.

However, if an industry is subject to Jacobs externalities, a diverse industrial structure enhances growth (Glaeser 1999; Henderson 1997). Jacobs externalities result from local industrial diversity (Jacobs 1969, 1984). A diverse industrial structure first of all means that the client base can be more diverse and therefore protect an industry from volatile demand. On the other hand, not only the clientele's diversity is beneficial, but also the width of the spectrum of locally available inputs is of value, as it facilitates switching between input substitutes in case of scarcity or a rise in prices. Lastly here as well, knowledge spillovers play a part: in a Schumpeterian setting it is often argued that the most radical innovations are derived from a combination 
Table 1 Hypothesised relations between agglomeration externalities and growth according to MAR, Jacobs and Porter

Source Van Oort (2007)

\begin{tabular}{llll}
\hline & MAR & Jacobs & Porter \\
\hline Specialization & + & - & + \\
Diversity & - & + & - \\
Competition & - & + & + \\
\hline
\end{tabular}

of ideas — пеие Kombinationen - from totally unrelated fields (Boschma and Lambooy 2002). Hence, a higher degree of diversity may increase the probability of discovering radically new products or solutions to problems in the production process. Upgrading these dynamics to the level of a city one can argue that by presence of Jacobs externalities, external economies will be available to all local firms irrespectively of sector, which have a positive effect on overall city diversity and productivity. By the presence of MAR externalities, localized productivity is augmented by concentration on a specific number of sectors (Dissart 2003). Taking this rationale into account, it is plausible to argue that, on the scale of the industrial site these dynamics are even more manifest.

The third externality to be mentioned explicitly is competition. Combes (2000) argues that the impact of competition on growth is non-linear. Schumpeterian models underline this trade-off: high competition provides firms incentives to make important $R \& D$ investment, but, if the succession of innovations is too fast, returns from $R \& D$ are low, which reduces the amount of $R \& D$ and this in turn has a negative impact on innovations (see also Aghion and Griffith 2005). These notions go back to Schumpeter (1942) who predicted that local monopoly is better for growth than local competition; after all, local monopoly restricts the flow of ideas and so allows externalities to be internalized by the innovator. In contrast, Porter (1990) argued that local competition in specialized, geographically-concentrated industries stimulates growth. This is partially in accordance with MAR and partially in accordance with Jacobs. Table 1 summarizes the aforementioned agglomeration conditions under which externalities affect growth, according to MAR, Jacobs and Porter.

Many empirical studies (e.g., Glaeser et al. 1992; Henderson 1997; Frenken et al. 1999; Glaeser 1999; Henderson 2003; Frenken et al. 2007) have tried to explain the performance of cities or regions by examining the role of MAR, Jacobs and Porter externalities. In general, the literature presents conflicting evidence about the relevance of these externalities. While Henderson $(1997,2003)$ finds that only MAR externalities are relevant for traditional manufacturing and for new high-tech industries, Glaeser et al. (1992) argue for the importance of Jacobs and Porter externalities. De Groot et al. (2007) present a meta-analysis describing the available evidence and explaining its variation, based on 31 studies, which build on the seminal work of Glaeser et al. (1992). They conclude that the evidence in the literature on the role of the specific externalities is rather mixed: relatively many primary studies demonstrate significantly positive effects of diversity and competition on growth. They found no clear-cut evidence for the effects of specialisation.

In summary, on the city level it can be argued that the level of specialization, diversification, and competition, caused by both MAR, Jacobs externalities, and Porter externalities exert an influence on city performance. Although the nature of the relationship between the different externalities and performance of a city is rather 
complex, it provides a useful framework to analyse industrial sites to which we turn in the remainder of this paper.

\section{Data set and research set up}

With the difference that our study concerns a different country and a different spatial unit of observation, we apply to a large extent the methodology of Glaeser et al. (1992). The reason for this is twofold. First, Glaeser et al. (1992) provide a tailormade framework, requiring a rather limited amount of data, for analysing the growth of geographical units on a disaggregated level. Moreover, a growing literature suggests that externalities tend to become stronger as the geographical units of reference become smaller (Bapstista 2000; Wallsten 2001). As the locus of Glaeser's analysis is the city, we choose the industrial site as locus of our analysis. By looking through a magnifying glass on locations of economic activity, in this case-study on industrial sites, we get detailed insight into the agglomeration mechanism on a low geographical scale of aggregation. In accordance with this approach we employ the often used implicit assumption that each region can be considered as a closed economy (Combes and Overman 2004). Therefore, the local employment growth of an industrial site is only linked to its own economic composition.

Second, employment is a vital indicator in local industrial site policy, which makes the Glaeser study an interesting precedent since it uses employment growth as indicator of performance. Local authorities consider the provision of industrial sites as a key instrument of their economic policy. ${ }^{3}$ In accordance with their task and responsibility as industrial land provider, local authorities ensure that there is always a minimum amount of industrial land available for immediate sale to interested companies. Likewise, industrial land provision in the municipality of Amsterdam follows this Dutch tradition (DRO 2006). Figure 1 gives an impression of the distribution of industrial land in the Amsterdam municipality. Consequently, increasing employment levels are a main argument by local politicians to develop industrial sites. This is underpinned by Bak (1985) who argues that in the Netherlands industrial sites are merely developed to meet local economic objectives, i.e. municipalities attempt to facilitate local entrepreneurship and competitiveness.

What is evident from Fig. 1 is that most of the industrial sites are either located close to the ringroad around the city centre or in the harbour area which is located in the North-Western part of the city along the 'Noordzeekanaal' and the Eastern part in the direction of the 'IJmeer'. The city-centre is located central in the area surrounded by the ringroad and stretches out towards the South from the riverside ('Het IJ').

We use data on employment and establishments on industrial sites in Amsterdam. This data originates from the 1998 to 2006 editions of the Monitor of Employment on Business Locations (Monitor Werkgelegenheid Bedrijfslocaties), produced by the

\footnotetext{
3 In general, an industrial site can be considered as a collective location for the establishment of firms (Bak 1985). In this study, however, we use a more narrow definition for the concept of industrial site: a location which the land-use plan deems suitable for activities in the branches of commerce, manufacturing, commercial services and industry (Louw 2000). Sites that are designated exclusively for offices are not covered by this definition.
} 


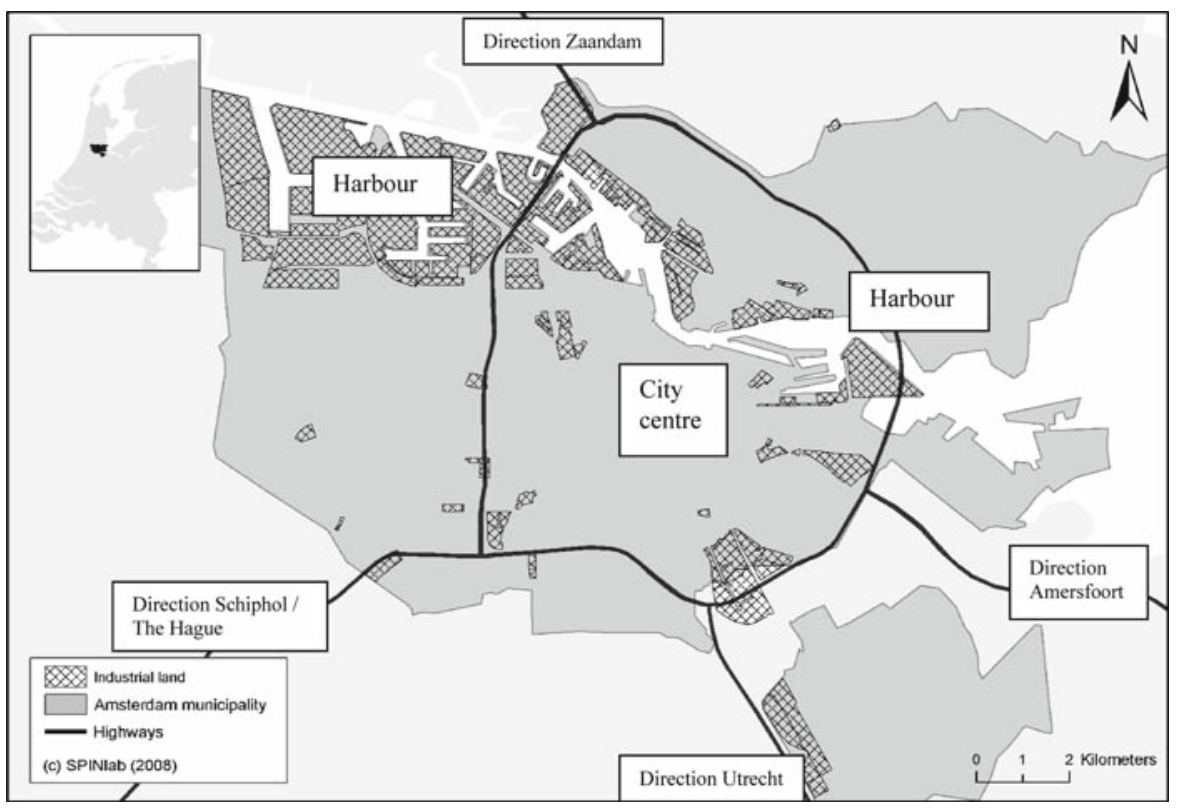

Fig. 1 Distribution of industrial land in the Amsterdam region (January 1, 2006)

Source Department for Research and Statistics, City of Amsterdam

Department for Research and Statistics (Dienst Onderzoek en Statistiek) of the city of Amsterdam. It provides each industrial site's employment level by industry. Besides the employment level, it contains the number of establishments by industry per industrial site. The data cover 68 formal industrial sites (see Appendix I), defined as such by the Department for Research and Statistics. ${ }^{4}$ The total number of industrial sites concerned corresponds to 3,437 hectares of (gross) industrial land in 2006, while the total Amsterdam area (residential housing, industrial, offices, infrastructure and water) comprises 21,939 hectares (O+S Amsterdam 2006). To get an impression of the importance of industrial sites, we can look at Table 2. We see that in 2006 around $20 \%$ of the total employment in Amsterdam was located on industrial sites $(\mathrm{O}+\mathrm{S}$ Amsterdam 2006). Compared with 1998, this is a slight increase. In addition, sites exclusively designated for offices cover around a quarter of the total employment in Amsterdam. But since we are interested in business locations denoted as industrial sites, and their performance, we do not include office locations in our analysis. The large share of 'other locations', or informal locations (not a formal, land-use policy designated collective site), is noticeable. Considering the average number of workers per firm, it becomes clear that smaller firms are largely located at other locations. This can be explained, taking into account the availability of space on business locations versus

\footnotetext{
4 The definition of industrial sites by the Department for Research and Statistics differs slightly from the definition of the Dutch Industrial Sites Database (IBIS), resulting in a different number of sites in our study than measured in IBIS. We omitted three sites, viz. AMC, Medisch Centrum Slotervaart and Lutkemeerpolder. This is done because these sites, sometimes called 'solitary sites', contain just one firm or agency.
} 
Table 2 Division of employment, number of firms, and average firm size (number of employees per firm), by location in Amsterdam (number employees and firms in thousands)

\begin{tabular}{|c|c|c|c|c|c|c|}
\hline \multirow[t]{2}{*}{ Location } & \multicolumn{3}{|l|}{ January 1, 1998} & \multicolumn{3}{|l|}{ January 1, 2006} \\
\hline & Employees & Firms & $\begin{array}{l}\text { Average } \\
\text { firm size }\end{array}$ & Employees & Firms & $\begin{array}{l}\text { Average } \\
\text { firm size }\end{array}$ \\
\hline Industrial sites & $66.942(18.9 \%)$ & $4.744 \quad(9.5 \%)$ & 14.11 & $83.134(20.1 \%)$ & $5.599(9.4 \%)$ & 14.85 \\
\hline Office locations & $81.425(23.0 \%)$ & $2.446(4.9 \%)$ & 33.29 & $103.720(25.0 \%)$ & $2.885(4.8 \%)$ & 35.95 \\
\hline Other locations & $205.064(58.0 \%)$ & $42.889(85.6 \%)$ & 4.78 & $227.439(54.9 \%)$ & $51.293(85.8 \%)$ & 4.43 \\
\hline Total Amsterdam & 353.431 & 50.079 & 7.06 & 414.293 & 59.784 & 6.93 \\
\hline
\end{tabular}

Source Department for Research and Statistics, City of Amsterdam

Note Share of total economic activity by type of location in parentheses. 'Other locations' are locations of establishment on sites that have not been designated by land-use policy

Table 3 Division of employment, number of firms, and average firm size (number of employees per firm) on Amsterdam industrial sites (number of employees and firms in thousands)

\begin{tabular}{|c|c|c|c|c|c|c|}
\hline \multirow[t]{2}{*}{ Location } & \multicolumn{3}{|l|}{ January 1,1998} & \multicolumn{3}{|l|}{ January 1, 2006} \\
\hline & Employees & Firms & $\begin{array}{l}\text { Average } \\
\text { firm size }\end{array}$ & Employees & Firms & $\begin{array}{l}\text { Average } \\
\text { firm size }\end{array}$ \\
\hline $\begin{array}{l}\text { Common industrial } \\
\text { sites }\end{array}$ & $57.200(85.4 \%)$ & $4.204(88.6 \%)$ & 13.61 & $70.053(84.3 \%)$ & $4.840(86.4 \%)$ & 14.47 \\
\hline Harbour sites & $9.742(14.6 \%)$ & $0.540(11.4 \%)$ & 18.04 & $13.081(15.7 \%)$ & $0.759(13.6 \%)$ & 17.23 \\
\hline Industrial sites & 66.942 & 4.744 & 14.11 & 83.134 & 5.599 & 14.85 \\
\hline
\end{tabular}

Source Department for Research and Statistics, City of Amsterdam

Note Share of total economic activity by type of location in parentheses

(inner-city) informal locations. Formal business locations are in principle designed to accommodate, mostly large-scale, economic activities which harm the environment or housing conditions by, amongst others, noise nuisance, air pollution and traffic inconvenience (Louw et al. 2004).

Table 3 presents the developments on the sites concerned. It shows a relative shift of employment and number of firms towards harbour sites in the period 1998-2006. Besides what are called 'common industrial sites', 'harbour sites' have been distinguished separately. Like the name already denounces, it concerns locations with harbour facilities. These harbour sites, or simply harbours, are mainly characterized by transport activities and large-scale industry. In Amsterdam, harbour sites represent $15 \%$ of total employment on industrial sites.

The industrial sites concerned are all located within the borders of the municipality of Amsterdam, with the exception of parts of Weespertrekvaart Zuid and Amstel I and the complete industrial site Amstel II, which is located in the adjacent municipality of Ouder-Amstel. The employment level is measured as the number of workers, working 12 hours or more per week. The total number of establishments and the employment figures are classified by economic activity; the Research and Statistics Department employs the Standard Industrial Classification 1993 (SIC 93) of Statistics Netherlands 
Table 4 Industry division on industrial sites (number of employees in thousands)

\begin{tabular}{lcc}
\hline Industry & \multicolumn{2}{l}{ Number of employees } \\
\cline { 2 - 3 } & January 1, 1998 & January 1, 2006 \\
\hline Renting and commercial services (K) & 12.758 & 22.954 \\
Trade and repair of consumer articles (G) & 15.874 & 17.331 \\
Transport, storage and communications (I) & 8.610 & 13.462 \\
Manufacture; Public Utilities (D, E) & 14.686 & 9.675 \\
Construction (F) & 5.533 & 5.848 \\
Environment, culture and other services (O) & 1.944 & 3.834 \\
Public administration, defence and social security (L) & 2.851 & 3.821 \\
Health and social work (N) & 1.499 & 2.948 \\
Financial intermediation (J) & 1.925 & 1.439 \\
Education (M) & 0.915 & 1.077 \\
Hotels and restaurants (H) & 0.347 & 0.745 \\
Total number of employees & 66.942 & 83.134 \\
\hline
\end{tabular}

Source Department for Research and Statistics, City of Amsterdam

Note SIC 93-code of industry concerned in parentheses

(CBS). Table 4 describes the eleven economic sectors involved in the sample, together with the associated number of employees. ${ }^{5}$

It appears that renting and commercial services $(\mathrm{K})$ is the most prevalent category represented on Amsterdam industrial sites in 2006. Overall, service categories are well represented on industrial sites in Amsterdam. This is consistent with De Groot et al. (2007) who find in their analysis of spatial distribution of economic activity in the Netherlands that the region of Amsterdam faces substantial location economies with regard to services, in particular to culture, compared to the rest of the Netherlands. Taking into consideration the availability of office locations, it is quite remarkable that services are represented to such an extent at industrial sites. One would expect a dominance of industrial sectors on industrial sites.

Besides examining agglomeration externalities, we also consider the importance of accessibility as a growth-promoting factor for industrial sites. Martin (1999) argues that spatial agglomeration models suffer from being too abstract and oversimplified as in the end they neglect real places. To take note of these real places, we consider non-contiguous spatial aspects based on the location of an industrial site. Such a non-contiguous spatial aspect of consideration is physical accessibility. In numerous business surveys accessibility has been ranked as a very important location factor (Hoogstra and Van Dijk 2004). We measure the ease of accessibility by the distance

\footnotetext{
5 Given that we examine industrial sites in the highly urbanized context of Amsterdam, it is evident that the category 'agriculture, hunting and forestry; fishing; mining and quarrying' (SIC 93-code A, B, C) is poorly represented. In 1998 and 2006, respectively, only 27 and 93 workers appear to be present in this category. Therefore, as we are interested in the variation in growth across site-industries, we do not take into account this small category $(\mathrm{A}, \mathrm{B}, \mathrm{C})$.
} 
of an industrial site to its nearest highway exit. ${ }^{6}$ By applying a cut-off distance of 1 kilometre, we distinguish relatively easy accessible industrial sites from less accessible sites. As a consequence, our sample comprises 26 industrial sites being well accessible (see Appendix I). Hence, we extend the initial analysis by controlling for elements of space (viz. accessibility).

\section{Measuring performance}

Following the framework developed by Glaeser et al. (1992), we use sectoral employment data of the different industrial sites concerned. More specifically, through a cross-section of 'site-industries', we examine the employment growth rates of the sectors on industrial sites concerned as a function of, among others, specialization, diversity, and competition. Glaeser et al. (1992) use the national situation as a benchmark in determining an externality of an individual city. In our study, this benchmark is replaced by the aggregate of industrial sites located in Amsterdam. The rationale for choosing this regional, or, strictly speaking, local benchmark is the scope of analysis: we merely examine the variation in growth of individual site-industries within the area of the municipality of Amsterdam.

The dependent variable in our analysis is defined as the average annual employment growth rate (GROWTH) in an industry $s(=1,2, \ldots, m)$ on a site $i(=1,2, \ldots, n)$ over the period 1998 to 2006 :

$$
\mathrm{GROWTH}_{s, i}=100 \cdot \ln \left(\frac{E_{s, i, 2006}}{E_{s, i, 1998}}\right) / 8,
$$

where $E$ denotes employment.

All explanatory variables are considered at January 1, 1998. The specialization index we consider is the ratio of the employment share of sector $s$ on industrial site $i$ divided by this ratio for the entire industrial area in Amsterdam. This specialization index is commonly known as the 'location quotient' (LQ):

$$
\mathrm{LQ}_{s, i}=\frac{E_{s, i} / \sum_{i=1}^{n} E_{s, i}}{\sum_{s=1}^{m} E_{s, i} / \sum_{s=1}^{m} \sum_{i=1}^{n} E_{s, i}} .
$$

The LQ is therefore the ratio of a location's share of industry employment to its share of aggregate employment. Values above (below) 1 imply that a certain sector is overrepresented (underrepresented) at a particular industrial site, as compared to the average situation in Amsterdam.

To test for Jacobs externalities, we use the relative diversity index (RDI), which equals the inverse of the Krugman specialization index (McCann 2001):

$$
\mathrm{RDI}_{i}=\frac{1}{\sum_{s}^{m}\left|\frac{E_{s, i}}{\sum_{i=1}^{n} E_{s, i}}-\frac{\sum_{s=1}^{m} E_{s, i}}{\sum_{s=1}^{m} \sum_{i=1}^{n} E_{s, i}}\right|}
$$

\footnotetext{
6 The proximity data (distance nearest highway exit to industrial site) taken from http://www. hetvirtuelebedrijventerrein.nl.
} 
In other words, RDI represents the extent to which the employment structure on a particular industrial site $i$ deviates from the employment structure of Amsterdam as a whole. The value of the relative diversity index increases as the site employment distribution approaches that of the overall distribution on Amsterdam industrial sites. By using this measure, we deviate from Glaeser et al.'s approach of measuring diversity, which focuses on the levels of employment among the six largest sectors in each city. To measure diversity, the employment share of the other five largest sectors in total employment of the city's employment is used. However, as many sites in our sample do not comprise six or more sectors, which is mainly due to the broad classification of industries and the limited size of some sites, we decide to adopt the relative diversity (RDI) to test for Jacobs externalities.

Competition is captured by measuring the number of establishments per employee (COMP) in the site-industry relative to establishments per employee in this industry on the overall Amsterdam industrial area:

$$
\operatorname{COMP}_{s, i}=\frac{F_{s, i} / E_{s, i}}{\sum_{s=1}^{m} F_{s, i} / \sum_{s=1}^{m} E_{s, i}}
$$

where $F$ denotes the number of firms. The application of this measure is in line with Glaeser et al. (1992), who consider the number of firms per worker as a proxy for competition. A value greater than 1 means that a specific industry contains more firms relative to its size on a industrial site vis-à-vis the total amount of industrial area in Amsterdam. Glaeser et al. (1992) reason that a value greater than 1 can be interpreted that the industry on a site is locally more competitive than it would be on a site elsewhere, in this case, in Amsterdam.

Similar to Glaeser et al. (1992), we control for initial employment by including the log of employment of the site-industry in $1998\left(\mathrm{EMP}_{s, i}\right)$. By including the log of the aggregate employment growth of the own industry in the analysis (based on overall employment in the industry on all industrial sites in Amsterdam) defined as AGGROWTH $_{s}$, we correct for aggregate demand shifts. ${ }^{7}$ The sample includes 422 observations. In contrast to Glaeser et al. (1992), who only consider the top six sectors, we count in all sectors, aside from 'agriculture'. However, none of the sectors concerned appears to be present at every individual site. Therefore, we observe 422 site-industries, instead of $748(11 \times 68)$ which would be the case if all distinguished sectors were present at the each industrial site. Table 5 provides descriptive statistics of the key variables in our analysis.

\section{Estimation results}

\section{Baseline model (OLS)}

In order to find empirical evidence of the relationship between employment growth across site-industries and the potential growth determinants described in the previous

\footnotetext{
$\overline{7 \text { Aggregate employment growth }}$ is defined as AGGROWTH AG $_{s}=100 \cdot \ln \left(\frac{\sum_{i=1}^{n} E_{s, i, 2006}}{\sum_{i=1}^{n} E_{s, i, 1998}}\right) / 8$.
} 
Table 5 Variable means, medians, and standard deviations (based on 422 observations)

\begin{tabular}{lllc}
\hline Variable & Mean & Median & Standard deviation \\
\hline Employment growth $\left(\mathrm{GROWTH}_{s, i}\right)$ & 2.40 & 0.80 & 16.56 \\
Log of employment 1998 $\left(\mathrm{EMP}_{s, i}\right)$ & 3.63 & 3.66 & 1.88 \\
Aggregate employment growth $\left(\mathrm{AGGROWTH}_{s}\right)$ & 2.79 & 2.04 & 4.99 \\
Specialization $\left(\mathrm{LQ}_{s, i}\right)$ & 1.68 & 0.76 & 3.12 \\
Diversity $\left(\mathrm{RDI}_{i}\right)$ & 1.27 & 1.21 & 0.44 \\
Competition $\left(\mathrm{COMP}_{s, i}\right)$ & 3.57 & 1.85 & 5.80 \\
\hline
\end{tabular}

Table 6 Site-industry average annual employment growth between 1998 and 2006

\begin{tabular}{|c|c|c|c|c|}
\hline & (1) & (2) & (3) & (4) \\
\hline Constant & $10.64^{* * *} \quad(6.14)$ & $10.69^{* * *} \quad(4.28)$ & $9.50^{* * *} \quad(4.37)$ & $10.31^{* * *} \quad(3.59)$ \\
\hline $\begin{array}{c}\text { Log of employment } \\
1998\left(\mathrm{EMP}_{s, i}\right)\end{array}$ & $-2.64 * * *(-6.39)$ & $-2.89^{* * *}(-7.04)$ & $-2.66^{* * *}(-5.85)$ & $-2.38^{* * *}(-4.88)$ \\
\hline $\begin{array}{l}\text { Aggregate growth } \\
\qquad\left(\mathrm{AGGROWTH}_{s}\right)\end{array}$ & $0.78^{* * *} \quad(5.16)$ & $0.74^{* * *} \quad(4.87)$ & $0.72^{* * *} \quad(4.84)$ & $0.78^{* * *} \quad(5.13)$ \\
\hline $\begin{array}{l}\text { Location quotient } \\
\qquad\left(\mathrm{LQ}_{s, i}\right)\end{array}$ & $-0.48^{* *}(-1.97)$ & & & $-0.51^{* *}(-1.96)$ \\
\hline $\begin{array}{l}\text { Relative diversity } \\
\text { index }\left(\mathrm{RDI}_{i}\right)\end{array}$ & & $(0.09)$ & & -0.84 \\
\hline $\begin{array}{l}\text { Competition } \\
\qquad\left(\mathrm{COMP}_{s, i}\right)\end{array}$ & & & (1.04) & $(0.91)$ \\
\hline$F$ & $32.95^{* * *}$ & $31.38^{* * *}$ & $31.81^{* * *}$ & $19.94^{* * *}$ \\
\hline Adjusted $R^{2}$ & 0.19 & 0.18 & 0.18 & 0.18 \\
\hline Number of observations & 422 & 422 & 422 & 422 \\
\hline
\end{tabular}

Note $t$-values in parentheses

$* *$ Significant at the $5 \%$ level; *** Significant at the $1 \%$ level

section, we estimate the following model by ordinary least squares (OLS):

$$
\begin{aligned}
\operatorname{GROWTH}_{s, i}= & \beta_{0}+\beta_{1} \mathrm{EMP}_{s, i}+\beta_{2} \mathrm{AGGROWTH}_{s}+\beta_{3} \mathrm{LQ}_{s, i}+\beta_{4} \mathrm{RDI}_{i} \\
& +\beta_{5} \mathrm{COMP}_{s, i}+\varepsilon_{s, i} .
\end{aligned}
$$

The results are shown in Table 6.

The control variables all have the expected signs. High initial employment in an industry on a site leads to lower subsequent employment growth. Employment change in an industry on a site is positively associated with aggregate industrial employment in the Amsterdam area. Considering the results on externalities, we observe a statistically significant negative effect of specialization (Table 6, Eq. 1). Looking at the relative importance of the externalities concerned, by means of standardized coefficients; we can argue that raising the location quotient by one standard deviation decreases the average annual employment growth rate of the site-industry by $9.1 \%$. This result is the opposite of the prediction of the MAR model. 
The effects of the other externalities (diversity and competition) on growth are statistically non-significant effects on growth. Nevertheless, considering the relative effect of the individual variables, Eq. 2 in Table 6 suggests a positive contribution of absence of diversity to growth: the higher the RDI (i.e. the more the industrial composition of the site corresponds with the overall distribution on Amsterdam industrial sites), the faster the site-industry grows. In other words, as we augment the RDI by 0.44 (a standard deviation), average annual employment growth rate increases by $0.4 \%$. Note that this result may be driven by omitted variable bias from which Eq. 2 may suffer. Comparing Eq. 2 with Eq. 4 (in Table 6) demonstrates a change of sign of the RDI parameter. Furthermore, Table 6 (Eq. 3) suggests a positive effect of competition on site-industry growth: increasing the measure of competition by one standard deviation (5.80) raises the growth rate in the site-industry by $5.3 \%$. Taking into consideration the magnitude of the standardized parameters of the abovementioned variables, it is clear-cut, irrespective of statistical significance, that specialization and competition have a larger effect on the average annual growth rate than diversity.

Accordingly, our analysis of site-industries provides no empirical evidence for the hypothesized relation between growth and, respectively, Jacobs and Porter externalities. This is confirmed by Eq. 4 in Table 6. Using all measures of externalities simultaneously results in significant estimates for specialization and non-significant estimates for diversity and competition. ${ }^{8}$

\section{Fixed effects}

The analysis, which to a high degree resembles Glaeser et al. (1992), does not take into account sector-specific characteristics nor industrial site-specific characteristics. As such, results may partly be driven by unobserved heterogeneity. Introducing 'fixed effects' in the current model allows us to control for these unobserved fixed, or unvarying characteristics. Although the unobserved characteristics can be seen as a 'black box'-we do not know which specific characteristics and to which extent each of these unknown characteristics affect the explanatory variables as such-it eliminates potentially large sources of bias.

We consider unobserved attributes of site-industry growth which are not the result of random variation, but do vary across sector or industrial site. Unlike the baseline OLS-model (5), in our fixed effects estimation the intercept is allowed to vary across site-industries but not over sector or site. Accordingly, we estimate two fixed effects models: a sector-specific version and an industrial site-specific version.

At first, in this subsection we address fixed effects associated with unobserved sectoral characteristics $\left(\alpha_{S}\right)$. Subsequently, we add industrial site-effects $\left(\alpha_{i}\right)$ to our original analysis. Adding sector-fixed effects to the original model results in the following equation:

\footnotetext{
8 Employing a panel analysis, dividing the period 1998-2008 in two different periods, viz. (1998-2002) and (2002-2006), gives similar results in terms of direction and significance. Details are available upon request.
} 
$\mathrm{GROWTH}_{s, i}=\alpha_{s}+\beta_{1} \mathrm{EMP}_{s, i}+\beta_{2} \mathrm{LQ}_{s, i}+\beta_{3} \mathrm{RDI}_{i}+\beta_{4} \mathrm{COMP}_{s, i}+\varepsilon_{s, i}$.

The unobserved effect, denoted as $\alpha_{s}$, is estimated for each sector $s$. The effect of variable AGGROWTH ${ }_{s}$ can no longer be identified, because it is sector-invariant and thus captured by $\alpha_{s}$.

When we take into consideration industrial site-fixed effects, the model becomes

$$
\mathrm{GROWTH}_{s, i}=\alpha_{i}+\beta_{1} \mathrm{EMP}_{s, i}+\beta_{2} \mathrm{AGGROWTH}_{s}+\beta_{3} \mathrm{LQ}_{s, i}+\beta_{4} \mathrm{COMP}_{s, i}+\varepsilon_{s, i} .
$$

The unobserved effect is specified as $\alpha_{i}$. This intercept is estimated for each industrial site. Compared to Eq. 5, we have omitted the variable $\mathrm{RDI}_{i}$ from the model, because RDI does not vary within the industrial sites.

The results of the both fixed-effects (FE) estimation methods are presented in Table 7. ${ }^{9}$ The fixed-effects estimation outcomes are reported vis-à-vis their pooled OLS counterpart ( $\alpha_{s}$ and $\alpha_{i}$, respectively, vary across sectors and industrial sites), which allows us to obtain insight into the possible correlation between the explanatory variables concerned and unobserved sector- and site-specific effects.

If we compare the sector-fixed effects estimation results (column 1) with the pooled OLS estimates (column 2) $-\alpha_{s}$ is constant across industrial sites-it results in some notable outcomes. Although, these fixed-effects results indicate that, when the impact of sector-specific unobserved heterogeneity is controlled for, the influence of local specialisation reduces. The same applies to diversity, whereas the influence of competition slightly increases. The specialization coefficient becomes statistically insignificant, while the other estimates remain statistically insignificant. Furthermore, examination of the coefficients of the sector-specific intercepts shows that the level of growth in the categories 'trade and repair consumer articles' (G), 'hotels and restaurants' $(\mathrm{H})$, 'transport, storage and communications' (I), 'renting and commercial services' (K), 'public administration, defence and social security' (L) and 'environment, culture and other services' $(\mathrm{O})$ is above average. Remarkable is the absence of 'financial intermediation $(\mathrm{J})$ in this bundle of well performing sectors. One would expect that 'financial intermediation', in view of the performance of other service-related sectors, would also display growth. A possible explanation could be found in the increasing portion of 'office locations' (see Table 1). It is likely that financial intermediation services have a preference for this type of location, given the nature of this industry and designation of the location. Like sector-fixed effects, the inclusion of industrial site-fixed effects results in some mutations of the original OLS outcomes (column 3). Most striking is the mutation of the statistical significance of, respectively, the specialization coefficient and competition coefficient. This outcome suggests that space, or more specific location, matters: the variation of unobserved

\footnotetext{
9 The reported constants in the fixed effects estimations should be interpreted as the average of the individual-specific intercepts. In this respect, the individual-specific intercepts $\alpha_{s}$ and $\alpha_{i}$ are denoted, respectively, as $S_{S}$ and $I_{i}$. The coefficients indicate the extent to which the magnitude of the specific fixed effects deviates from the average of all estimated fixed effects.
} 
Table 7 Site-industry average annual employment growth between 1998 and 2006

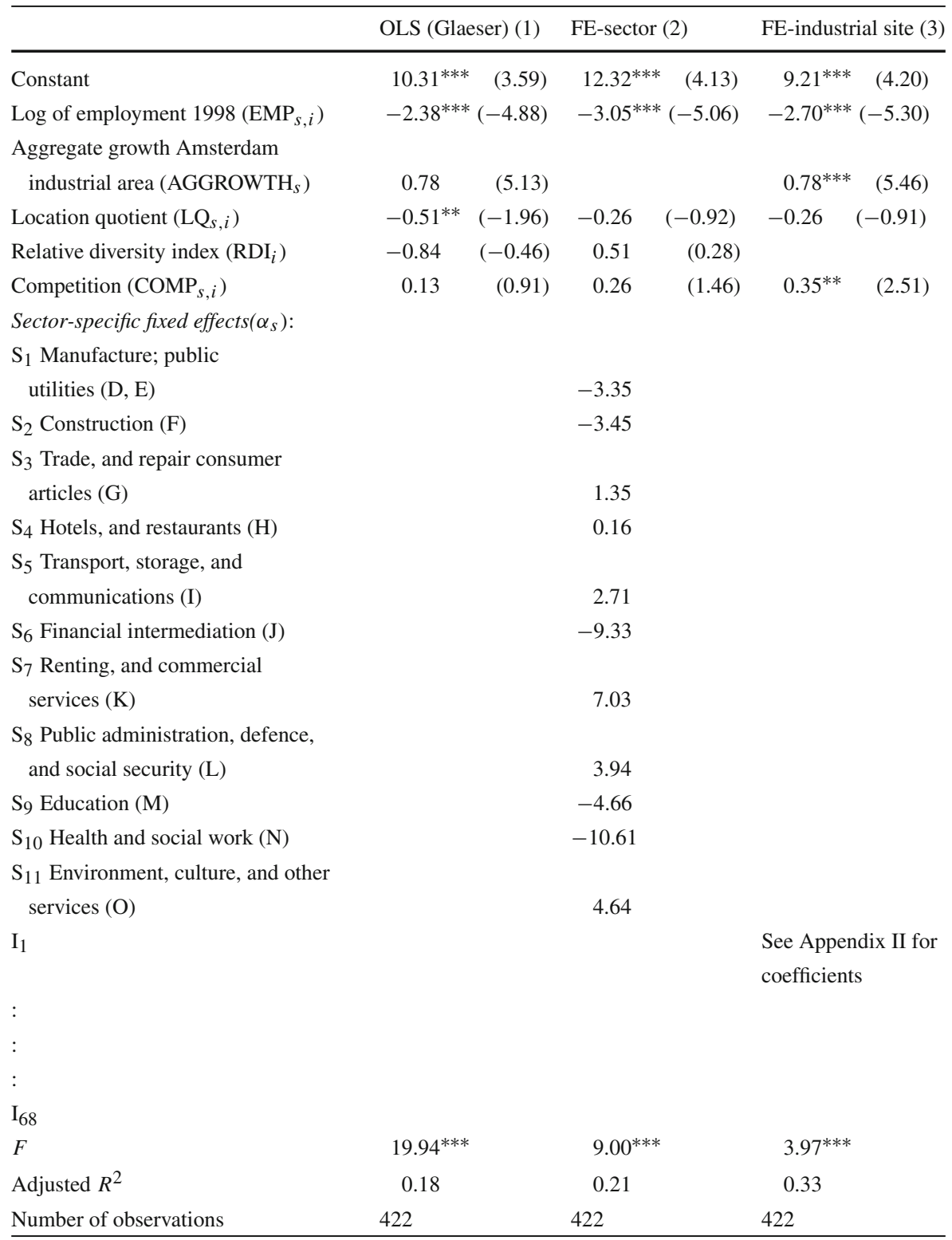

$t$-values in parentheses. SIC 93-code of corresponding industry in parentheses behind sector-specific intercepts

$* *$ Significant at the $5 \%$ level; *** Significant at the $1 \%$ level

industrial site-specific characteristics is to a certain extent responsible for the observed variation of site-industry growth across industrial sites. The decline of the LQcoefficient suggests that there is a correlation between local specialization and the 


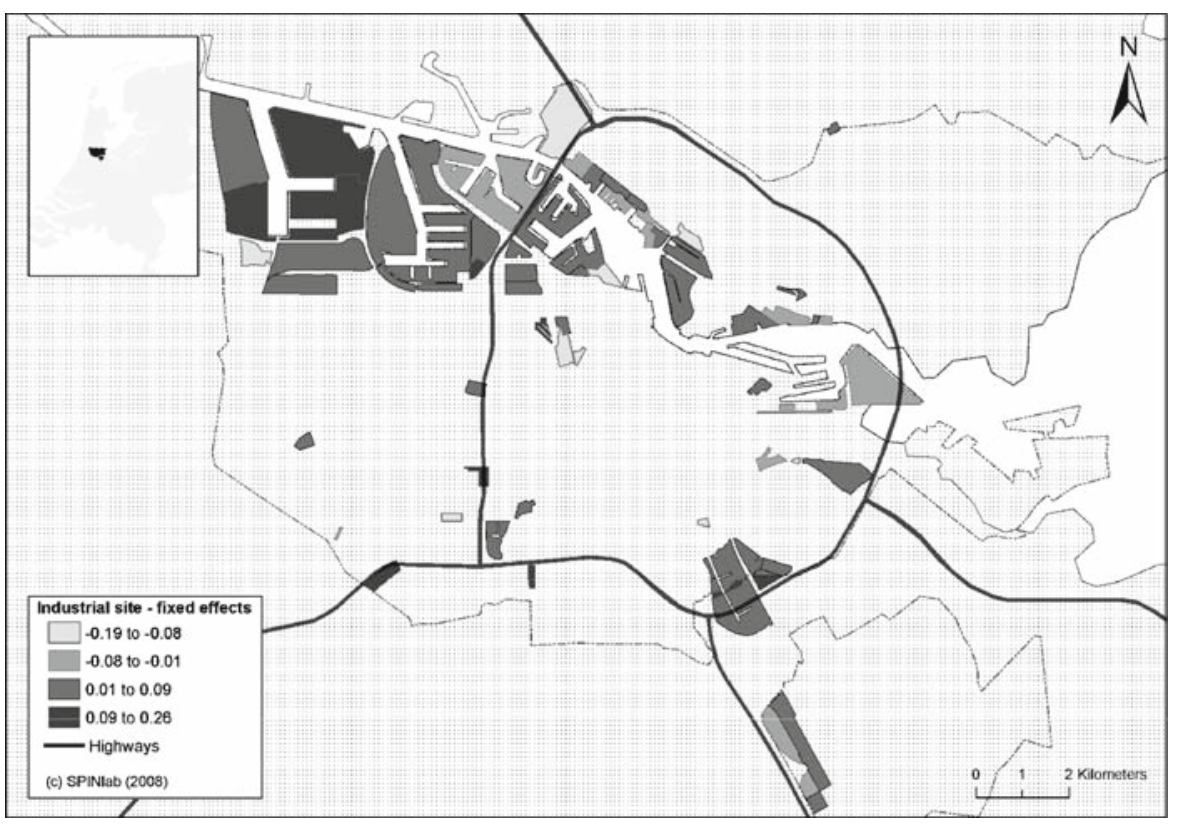

Fig. 2 Spatial distribution of site-specific effects in Amsterdam

industrial site concerned. In other words, the degree of specialization appears to be correlated with unvarying, industrial site-specific, unobserved factors that affect employment growth on a site-industry. Controlling for industrial site-specific fixed effects increases the competition coefficient significantly, the point estimate rising to 0.35 .

In Fig. 2, we have mapped the site-specific effect coefficients by industrial site to display the performance of individual industrial sites. Besides information about the performance of individual sites, it also provides information about the possible clustering of (more or less) equally performing sites. The uneven distribution of growth across industrial sites may indicate the occurrence of specific circumstances that determines this pattern of growth. Tentatively, we can infer that, as a result of the observed clustering patterns, the North-Western and the South-Eastern part of the area face specific circumstances influencing performance on the industrial sites concerned.

\section{Spatial heterogeneity}

Due to our particular interest in the importance of accessibility as a growth-promoting factor, we elaborate on the issue of geographical context-specificity. We model spatial heterogeneity to control for this location-specific attribute.

Introducing space is legitimated by various studies that have used a comparative framework of agglomeration externalities reporting mixed evidence for which type of externality matters most for economic growth (Burger et al. 2007; De Groot et al. 
2007). Besides different effects of agglomeration externalities on economic growth across sectors and time periods, different effects are identified across spatial regimes. Moreover, the degree of (non-) robustness and inconsistency can be traced back to the scale-dependency of agglomeration externalities. In this respect, Van Oort (2007) argues that results are better controlled for local-specific attributes when analysed on lower spatial scales (detailed municipal level of the Netherlands). Furthermore, it is argued that research results are more informative when non-contiguous spatial regimes on various scales are tested. In accordance with these findings, we may introduce space in our model. The outcomes of the additional analysis concerning fixed effects suggest that location matters.

Figure 2 shows us an uneven distribution —or clustering — of growth which reflects possible forces referring to (geographical) context-specificity. The clusters are positioned in the geographical context of the well-accessible periphery (South-Eastern border) as well as in the geographical context of the harbour area (North-West). Besides it may emphasize effects of accessibility, it implies that forces associated with localization in the harbour area are involved. Possible heterogeneity in these spatial dimensions may be taken into account in explaining variation in employment growth across industrial sites. ${ }^{10} \mathrm{~A}$ way of revealing this spatial heterogeneity is taking into account non-contiguous spatial aspects based on the location of an industrial site. Spatial heterogeneity means variation over space of the relationships under study. More precisely, it implies that functional forms and parameters vary with location and are not homogenous throughout the data set (Anselin 1988). In view of the nature of our analysed spatial entities (viz. industrial sites), it is reasonable to capture spatial heterogeneity by identifying location's specific characteristics. In this respect, we consider the following specific characteristics: physical accessibility and harbour.

We construct a dummy-variable, $\mathrm{ACC}_{i}$, indicating the ease of accessibility of the highway (where the dummy equals one for sites within 1 kilometre of a highway exit). ${ }^{11}$ Besides accessibility, we construct a dummy-variable $\left(\mathrm{HARB}_{i}\right)$ equal to one for a site-industry being located at a harbour site (see Appendix I). Taking into account these dummies results in the following regression model:

$$
\begin{aligned}
\operatorname{GROWTH}_{s, i}= & \beta_{0}+\beta_{1} \mathrm{EMP}_{s, i}+\beta_{2} \mathrm{AGGROWTH}_{s}+\beta_{3} \mathrm{LQ}_{s, i}+\beta_{4} \mathrm{RDI}_{i} \\
& +\beta_{5} \mathrm{COMP}_{s, i}+\beta_{6} \mathrm{ACC}_{i}+\beta_{7} \mathrm{HARB}_{i}+\varepsilon_{s, i} .
\end{aligned}
$$

The estimation results are presented in Table 8. We report these 'extended' estimation outcomes vis-à-vis their pooled OLS equivalent (see Table 6, Eq. 4).

The highly statistically significant and qualitatively large effects concerning being located within 1 kilometre from a highway exit and presence at a harbour site provides us with sound insight into the closed black box of unobserved site-characteristics. The

\footnotetext{
${ }^{10}$ Spatial heterogeneity is often associated with another spatial effect: namely, spatial dependence, or spatial autocorrelation. This contiguous counterpart of spatial heterogeneity exists when the dependent variable in a model is dependent on neighboring values (contiguous nearness) of this dependent variable (Van Oort 2007).

11 The proximity data (distance nearest highway exit to industrial site) have been derived from http://www.hetvirtuelebedrijventerrein.nl.
} 
Table 8 Site-industry average annual employment growth between 1998 and 2006, controlling for presence at harbour site and accessibility

\begin{tabular}{|c|c|c|}
\hline & $\begin{array}{l}\text { OLS (Glaeser) } \\
\text { (see eq. 5) }\end{array}$ & $\begin{array}{l}\text { OLS extended } \\
\text { (see eq. } 8 \text { ) }\end{array}$ \\
\hline Constant & $10.31^{* * *} \quad(3.59)$ & $8.63^{* * *} \quad(3.04)$ \\
\hline Employment $1998\left(\mathrm{EMP} 8_{s, i}\right)$ & $-2.38^{* * *}(-4.88)$ & $-2.66^{* * *}(-5.52)$ \\
\hline $\begin{array}{l}\text { Aggregate growth Amsterdam } \\
\text { industrial area }\left(\mathrm{AGGROWTH}_{s}\right)\end{array}$ & $0.78^{* * *} \quad(5.13)$ & $0.77^{* * *} \quad(5.17)$ \\
\hline Location quotient $\left(\mathrm{LQ}_{s, i}\right)$ & $-0.51^{* *}(-1.96)$ & $-0.49^{* *}(-1.93)$ \\
\hline Relative diversity index $\left(\mathrm{RDI}_{i}\right)$ & $(-0.46)$ & $(-0.73)$ \\
\hline Competition $\left(\mathrm{COMP}_{s, i}\right)$ & $(0.91)$ & $(1.13)$ \\
\hline Dummy distance to highway exit $(<1 \mathrm{~km})\left(A C C_{i}\right)$ & & $6.05^{* * *} \quad(3.86)$ \\
\hline \multicolumn{3}{|l|}{ Dummy harbour site $\left(H A R B_{i}\right)$} \\
\hline & & $7.63^{* * *} \quad(3.29)$ \\
\hline$F$ & $19.94^{* * *}$ & $17.70^{* * *}$ \\
\hline Adjusted $R^{2}$ & 0.18 & 0.23 \\
\hline Number of observations & 422 & 422 \\
\hline
\end{tabular}

Note $t$-values in parentheses. SIC 93-code of corresponding industry in parentheses behind sector-specific intercepts.

** Significant at the $5 \%$ level; *** Significant at the $1 \%$ level

coefficient regarding ease of accessibility conveys $6.1 \%$ higher average annual growth vis-à-vis poorly accessible sites. Furthermore, harbour sites render $7.6 \%$ higher growth than non-harbour sites. By revealing these spatial effects, it is confirmed that employment growth, on the (detailed) site-industry level in the Amsterdam municipality, is sensitive to non-contiguous elements of space.

However, the inclusion of fixed effects in the original Glaeser model has been legitimated, as inclusion effectively eliminates large sources of bias and indicates that, respectively, unmeasured sector-specific and site-specific aspects are involved. This firstly points out that the initial Glaeser model is limited in explaining employment growth in site-industries. Although, by adding sector-fixed and industrial site-fixed effects one can infer the importance of accessibility and the presence at a harbour site as determinants of localized employment growth. Despite the relative small sample we are able to get insight in mechanisms of explaining variation of localized growth across industrial sites, but expansion of the sample is preferable. Since we only examine the situation in municipality of Amsterdam, expanding the sample size would increase the variation which could result in more profound findings considering the occurrence of agglomeration externalities on industrial sites and the influence of spatial effects on the strength of these externalities. The latter specifically refers to the aspect of context-specificity of the performance of an industrial site.

\section{Conclusion and discussion}

The main aim of this paper is to study the performance of industrial sites and to investigate the relationship between the degree of local specialization, local diversity 
and local competition on industrial sites and the performance of industries on these sites. We operationalize performance of industrial sites by taking the employment growth of a certain industry on a certain site. In order to explain the variation in employment growth across the site-industries concerned, we regress (pooled OLS) growth on measures of specialization, diversity and competition. By taking industrial sites located within the area of the municipality of Amsterdam, we show to what extent the economic structure, in terms of specialization, diversity and competition, affects site-industry employment growth between 1998 and 2006. The outcomes of our analysis exhibit substantial empirical evidence of a negative relationship between the degree of specialization and growth (statistically significant at the 5\% level). This implies that an overrepresentation of similar economic activity does not generate substantial localization economies.

Extension of the Glaeser model by adding fixed effects provided, amongst other things, support to the notion that location matters, or at least the position of an industrial site. The parameterization of unobserved characteristics generates a 'black box'. As we are particularly interested in the importance of accessibility we focus on location characteristics. Therefore, adding (non-contiguous) indicators of spatial heterogeneityease of accessibility and presence at a harbour site-helps us disclosing this black box to a certain degree: well-accessible sites convey $6.1 \%$ higher average annual growth vis-à-vis poorly accessible sites, and harbours render $7.6 \%$ higher growth than nonharbours.

Spatial heterogeneity denotes variation over space of the relationships under study (Anselin 1988). In our case, the inclusion of non-contiguous spatial aspects deals with the variation of intercepts, but does not with parameter variation across industrial sites. In this respect, further research is recommendable. In view of the nature of our analysed spatial entities (viz. industrial sites), further investigation of homogeneity of the relationship between agglomeration externalities and employment growth over space is needed. Another challenge for further research would be to extend the analysis by contiguous elements of space. Since our study is mainly built on Glaeser et al. (1992), we treat agglomeration externalities as spatially fixed; we neglect the issue of spatial dependence. In other words, to what extent is performance on a site affected by the growth of neighbouring industrial sites? It is assumed that the spatial dependence of growth attenuates with distance (Rosenthal and Strange 2004). In this respect, Van Oort (2007) reports that the inclusion of spatially lagged versions of explained variables and explanatory variables gives rise to ambiguous results. It seems that the results differ by geographic scale. Despite the relative small sample, Glaeser's model has enabled us to get insight in the extent of which performance of an industrial site is affected by its local economic structure and accessibility. As such, it may provide useful tools to policymakers and urban planners for prioritizing and assessing the (re)development of industrial sites.

Acknowledgments This research has been funded by the BSIK-programme 'Vernieuwend Ruimtegebruik'. The authors gratefully acknowledge the Department of Research and Statistics of the municipality of Amsterdam for providing the data for employment and establishments on industrial sites in Amsterdam. They thank Erik Louw, Frank van Oort, Piet Rietveld and two anonymous reviewers of this journal for their helpful comments. They also thank Laura de Dominicis and Chris Jacobs for their assistance in preparing the maps. The usual disclaimer applies. 
Open Access This article is distributed under the terms of the Creative Commons Attribution Noncommercial License which permits any noncommercial use, distribution, and reproduction in any medium, provided the original author(s) and source are credited.

\section{Appendix I}

See Tables 9 and 10

Table 9 Industrial sites in Amsterdam

\begin{tabular}{|c|c|c|c|}
\hline \multicolumn{2}{|c|}{ Industrial site } & \multirow{2}{*}{$\frac{\text { Acc. }}{0}$} & \multirow{2}{*}{$\frac{\text { Harb }}{1}$} \\
\hline 1 & Amerikahaven Noordwest & & \\
\hline 2 & Amerikahaven Zuidwest & 0 & 1 \\
\hline 3 & Amerikahaven Noordoost & 0 & 1 \\
\hline 4 & Amerikahaven Zuidoost & 0 & 1 \\
\hline 5 & Westhaven West & 0 & 1 \\
\hline 6 & Westhaven Oost & 0 & 1 \\
\hline 7 & Petroleumhaven eo. & 0 & 1 \\
\hline 8 & Coenhaven & 0 & 1 \\
\hline 9 & Mercuriushaven & 0 & 1 \\
\hline 10 & Vervoerscentrum & 0 & 0 \\
\hline 11 & Alfa-driehoek Bedrijven & 1 & 0 \\
\hline 12 & Sloterdijk III Noord & 0 & 0 \\
\hline 13 & Sloterdijk III Zuid & 0 & 0 \\
\hline 14 & Bedrijvencentrum Osdorp & 0 & 0 \\
\hline 15 & Oude Haagseweg West & 1 & 0 \\
\hline 16 & Confectiecentrum & 1 & 0 \\
\hline 17 & Schinkel & 1 & 0 \\
\hline 18 & Bedrijvencentrum Westerpark & 0 & 0 \\
\hline 19 & Food Center Amsterdam & 0 & 0 \\
\hline 20 & Buyskade & 1 & 0 \\
\hline 21 & Landlust & 1 & 0 \\
\hline 22 & Houthavens Oost & 0 & 0 \\
\hline 23 & Noorder IJplas & 1 & 0 \\
\hline 24 & C Douwesterrein 0 & 0 & 0 \\
\hline 25 & C Douwesterrein $2 Z$ & 0 & 0 \\
\hline 26 & $\mathrm{C}$ Douwesterrein $4 \mathrm{~A}$ & 0 & 0 \\
\hline 27 & C Douwestterrein 5 & 0 & 0 \\
\hline 28 & C Douwesterrein 6 & 0 & 0 \\
\hline 29 & Buiksloterham & 0 & 0 \\
\hline 30 & Papaverweg & 0 & 0 \\
\hline 31 & Hamerstraat & 0 & 0 \\
\hline 32 & Zeeburgereiland & 1 & 0 \\
\hline 33 & Zeeburgerpad & 0 & 0 \\
\hline
\end{tabular}


Table 9 continued

Sources Department for Research and Statistics, City of Amsterdam. http://www. hetvirtuelebedrijventerrein. nl/locatiemonitor Notes Acc. accessibility ( 1 = within $1 \mathrm{~km}$ of highway exit, $0=$ outside $1 \mathrm{~km}$ of highway exit) Harb. harbour site (1=yes, $0=$ no)

\begin{tabular}{|c|c|c|c|}
\hline \multicolumn{2}{|c|}{ Industrial site } & \multirow{2}{*}{$\frac{\text { Acc. }}{0}$} & \multirow{2}{*}{$\frac{\text { Harb. }}{0}$} \\
\hline 34 & Cruquiusweg & & \\
\hline 35 & Kenniscentrum Amsterdam & 0 & 0 \\
\hline 36 & Weespertrekvaart Noord & 1 & 0 \\
\hline 37 & Weespertrekvaart Zuid Amsterdam & 1 & 0 \\
\hline 38 & Weespertrekvaart-Zuid Ouder-Amstel & 1 & 0 \\
\hline 39 & Weespertrekvaart Zuid A'dam/O Amstel & 1 & 0 \\
\hline 40 & Amstel I Amsterdam & 1 & 0 \\
\hline 41 & Amstel I Ouder-Amstel/Amsterdam & 1 & 0 \\
\hline 42 & Amstel II & 1 & 0 \\
\hline 43 & Amstel III deel C & 1 & 0 \\
\hline 44 & Amstel III deel D1 & 1 & 0 \\
\hline 45 & Amstel III deel D2 & 1 & 0 \\
\hline 46 & Sloterdijk II Noord & 1 & 0 \\
\hline 47 & Sloterdijk I Bedrijven Zuid & 1 & 0 \\
\hline 48 & Sloterdijk I bedrijven Noord & 1 & 0 \\
\hline 49 & Heining & 0 & 0 \\
\hline 50 & Zijkanaal I & 0 & 0 \\
\hline 51 & Metaalbewerkerweg & 0 & 0 \\
\hline 52 & Zamenhofstraat & 0 & 0 \\
\hline 53 & Pereboomsloot & 0 & 0 \\
\hline 54 & Gembo-terrein & 0 & 0 \\
\hline 55 & Nieuwendammerdijk & 0 & 0 \\
\hline 56 & 't Schouw & 0 & 0 \\
\hline 57 & Conradstraat & 0 & 0 \\
\hline 58 & Veemarkt & 0 & 0 \\
\hline 59 & Molukkenstraat & 0 & 0 \\
\hline 60 & Polderweg & 0 & 0 \\
\hline 61 & Tramremise Lekstraat & 0 & 0 \\
\hline 62 & Pompstation Waterleidingen Buitenve & 1 & 0 \\
\hline 63 & Jollenpad & 1 & 0 \\
\hline 64 & Karperweg & 0 & 0 \\
\hline 65 & Aletta Jacobslaan & 1 & 0 \\
\hline 66 & Jan Tooropstraat & 1 & 0 \\
\hline 67 & Sloten Slimmeweg & 0 & 0 \\
\hline 68 & Sloterdijk II Zuid & 1 & 0 \\
\hline
\end{tabular}




\section{Appendix II}

Table 10 Industrial site-fixed effects estimation

\begin{tabular}{|c|c|c|c|}
\hline Constant & $9.21^{* * *} \quad(4.20)$ & & \\
\hline Log of employment $1998\left(\mathrm{EMP}_{s, i}\right)$ & $-2.70^{* * *}(-5.30)$ & & \\
\hline $\begin{array}{l}\text { Aggregate growth Amsterdam } \\
\text { industrial area }\left(\mathrm{AGG} 9806_{s}\right)\end{array}$ & $0.78^{* * *} \quad(5.46)$ & & \\
\hline Location quotient $\left(\mathrm{LQ}_{s, i}\right)$ & $-0.26 \quad(-0.91)$ & & \\
\hline Competition $\left(\mathrm{COMP}_{s, i}\right)$ & $0.35^{* *} \quad(2.51)$ & & \\
\hline Industrial site & Fixed effect $\left(\alpha_{i}\right)$ & Industrial site & Fixed effect $\left(\alpha_{i}\right)$ \\
\hline $\mathrm{I}_{1}$ & 0.01 & $\mathrm{I}_{35}$ & 0.00 \\
\hline $\mathrm{I}_{2}$ & 0.17 & $\mathrm{I}_{36}$ & 0.06 \\
\hline$I_{3}$ & 0.10 & $\mathrm{I}_{37}$ & 0.03 \\
\hline $\mathrm{I}_{4}$ & 0.20 & $\mathrm{I}_{38}$ & 0.17 \\
\hline $\mathrm{I}_{5}$ & 0.01 & $\mathrm{I}_{39}$ & 0.01 \\
\hline $\mathrm{I}_{6}$ & 0.02 & $\mathrm{I}_{40}$ & 0.04 \\
\hline $\mathrm{I}_{7}$ & -0.03 & $\mathrm{I}_{41}$ & 0.13 \\
\hline $\mathrm{I}_{8}$ & 0.02 & $\mathrm{I}_{42}$ & 0.02 \\
\hline $\mathrm{I}_{9}$ & 0.05 & $\mathrm{I}_{43}$ & 0.05 \\
\hline $\mathrm{I}_{10}$ & 0.04 & $\mathrm{I}_{44}$ & -0.01 \\
\hline $\mathrm{I}_{11}$ & 0.06 & $\mathrm{I}_{45}$ & 0.06 \\
\hline $\mathrm{I}_{12}$ & 0.25 & $\mathrm{I}_{46}$ & 0.17 \\
\hline $\mathrm{I}_{13}$ & 0.07 & $\mathrm{I}_{47}$ & 0.04 \\
\hline $\mathrm{I}_{14}$ & 0.03 & $\mathrm{I}_{48}$ & 0.01 \\
\hline $\mathrm{I}_{15}$ & -0.14 & $\mathrm{I}_{49}$ & -0.19 \\
\hline $\mathrm{I}_{16}$ & 0.12 & $\mathrm{I}_{50}$ & -0.44 \\
\hline $\mathrm{I}_{17}$ & -0.00 & $\mathrm{I}_{51}$ & -0.09 \\
\hline $\mathrm{I}_{18}$ & 0.01 & $\mathrm{I}_{52}$ & -0.04 \\
\hline $\mathrm{I}_{19}$ & -0.07 & $\mathrm{I}_{53}$ & -0.00 \\
\hline $\mathrm{I}_{20}$ & -0.11 & $\mathrm{I}_{54}$ & -0.01 \\
\hline $\mathrm{I}_{21}$ & 0.11 & $\mathrm{I}_{55}$ & -0.06 \\
\hline $\mathrm{I}_{22}$ & -0.15 & $\mathrm{I}_{56}$ & 0.09 \\
\hline $\mathrm{I}_{23}$ & -0.19 & $\mathrm{I}_{57}$ & 0.01 \\
\hline $\mathrm{I}_{24}$ & -0.04 & $\mathrm{I}_{58}$ & -0.04 \\
\hline $\mathrm{I}_{25}$ & -0.03 & $\mathrm{I}_{59}$ & -0.17 \\
\hline $\mathrm{I}_{26}$ & -0.04 & $\mathrm{I}_{60}$ & -0.07 \\
\hline $\mathrm{I}_{27}$ & -0.05 & $\mathrm{I}_{61}$ & -0.11 \\
\hline $\mathrm{I}_{28}$ & 0.07 & $\mathrm{I}_{62}$ & 0.13 \\
\hline $\mathrm{I}_{29}$ & 0.02 & $\mathrm{I}_{63}$ & 0.16 \\
\hline $\mathrm{I}_{30}$ & 0.00 & $\mathrm{I}_{64}$ & 0.02 \\
\hline$I_{31}$ & 0.05 & $\mathrm{I}_{65}$ & -0.12 \\
\hline $\mathrm{I}_{32}$ & -0.04 & $\mathrm{I}_{66}$ & -0.00 \\
\hline $\mathrm{I}_{33}$ & -0.08 & $\mathrm{I}_{67}$ & -0.06 \\
\hline $\mathrm{I}_{34}$ & -0.04 & $\mathrm{I}_{68}$ & 0.03 \\
\hline
\end{tabular}


Table 10 continued

\begin{tabular}{ll}
\hline$F$ & $3.97^{* * *}$ \\
Adjusted $R^{2}$ & 0.33 \\
Number of observations & 422 \\
\hline
\end{tabular}

Note Additional regressors, in this case RDI, cannot be estimated in the FE-model due to occurrence of perfect collinearity

$* * *$ Significant at the $1 \%$ level; ** significant at the $5 \%$ level; * significant at the $10 \%$ level

\section{References}

Aghion P, Griffith R (2005) Competition and growth: reconciling theory and evidence. MIT Press, Cambridge

Anselin L (1988) Spatial econometrics: methods and models. Kluwer, Dordrecht

Bak L (1985) Collectieve Bedrijventerreinen in Nederland. Geografisch en Planologisch Instituut, Vrije Universiteit Amsterdam, Amsterdam (in Dutch)

Bapstista R (2000) Do innovations diffuse faster within geographical clusters? Int J Ind Organ 18:515-535. doi:10.1016/S0167-7187(99)00045-4

Boschma RA, Lambooy JG (2002) Knowledge, market structure and economic coordination: dynamics of industrial districts. Growth Change 33:291-311. doi:10.1111/1468-2257.00192

Breschi S, Lissoni F (2003) Mobility and social networks: localised knowledge spillovers revisited. CESPRI working papers 142. CESPRI, Milano

Burger M, van Oort FG, van der Knaap B (2007) A Treatise on the scale-dependency of agglomeration externalities and the modifiable areal unit problem. Paper prepared for the workshop on agglomoration and growth in knowledge-based societies, Kiel, Germany, 20-21 April 2007

Combes P (2000) Economic structure and local growth: France, 1984-1993. J Urban Econ 47:329-355. doi:10.1006/juec.1999.2143

Combes P, Overman HG (2004) The Spatial distribution of economic activities in the European Union. In: Henderson V, Thisse JF (eds) Handbook of Regional and Urban Economics, vol. 4. Elsevier, North Holland, Amsterdam

De Dominicis L, Florax RJGM, de Groot HLF (2007) De Ruimtelijke Verdeling van Economische Activiteit: Agglomeratie- en Locatievoordelen in Nederland, Faculteit der Economische Wetenschappen en Bedrijfskunde, FEWEB Research Memoranda no. 2007-18, Amsterdam (in Dutch)

De Groot HLF, Poot J, Smit MJ (2007) Agglomeration, innovation and regional development: theoretical perspectives and meta-analysis. Tinbergen Institute discussion paper, no. TI 2007-079/3, AmsterdamRotterdam

Dissart JC (2003) Regional economic diversity and regional economic stability: research results and agenda. Int Reg Sci Rev 26:423-446. doi:10.1177/0160017603259083

DRO (2006) Bedrijfslocaties in Amsterdam 2006. Amsterdam: Dienst Ruimtelijke Ordening, Gemeente Amsterdam (in Dutch)

Frenken K, Saviotti PP, Trommetter M (1999) Variety and Niche creation in aircraft, helicopters, motorcycles and microcomputers. Res Policy 28:496-488. doi:10.1016/S0048-7333(99)00008-6

Frenken K, van Oort FG, Verburg T (2007) Related variety, unrelated variety and regional economic. Reg Stud 41:685-697. doi:10.1080/00343400601120296

Glaeser EL (1999) Learning in cities. J Urban Econ 46:254-277. doi:10.1006/juec.1998.2121

Glaeser EL, Kallal H, Scheinkman J, Sheifler A (1992) Growth in cities. J Polit Econ 100:1126-1152. doi:10.1086/261856

Henderson JV (1997) Externalities and industrial development. J Urban Econ 42:449-470. doi:10.1006/ juec. 1997.2036

Henderson JV (2003) Marshall's scale economies. J Urban Econ 53:1-28. doi:10.1016/ S0094-1190(02)00505-3

Holmes TJ, Stevens JJ (2004) Spatial distribution of economic activities in North America. In: Henderson V, Thisse JF (eds) Handbook of urban and regional economics, vol. 4. Elsevier-North Holland, Amsterdam

Hoogstra GJ, Van Dijk J (2004) Explaining firm employment growth: does location matter? Small Bus Econ 22:179-192. doi:10.1023/B:SBEJ.0000022218.66156.ac 
Jacobs J (1969) The economy of cities. Vintage, New York

Jacobs J (1984) Cities and the wealth of nations. Random House, New York

Krugman P (1991) Geography and trade. MIT Press, Cambridge

Louw E (2000) Window on the Netherlands: the production of business sites in the Netherlands. Tijdschr Econ Soc Geogr 91:85-91. doi:10.1111/1467-9663.00095

Louw E, Needham B, Olden H, Pen CJ (2004) Planning van Bedrijventerreinen. Sdu Uitgevers, Den Haag (in Dutch)

Louw E, Bontekoning Y (2007) Planning of industrial land in the Netherlands: its rationales and consequences. Tijdschr Econ Soc Geogr 98:121-129. doi:10.1111/j.1467-9663.2007.00380.x

Marshall A (1890) Principles of economics. Macmillan, London

Martin R (1999) The new geographical turn in economics: some critical reflections. Camb J Econ 23:65-91. doi:10.1093/cje/23.1.65

McCann P (2001) Urban and regional economics. Oxford University Press, Oxford

O+S Amsterdam (2006) Amsterdam in Cijfers 2006. Dienst Onderzoek en Statistiek, Gemeente Amsterdam, Amsterdam (in Dutch)

O+S Amsterdam (2007) De Staat van de Stad Amsterdam IV. Dienst Onderzoek en Statistiek, Gemeente Amsterdam, Amsterdam (in Dutch)

Porter ME (1990) The competitive advantage of nations. Free Press, New York

Rosenthal SS, Strange WC (2004) Evidence on the nature and sources of agglomeration economies. In: Henderson V, Thisse JF (eds) Handbook of urban and regional economics, vol 4. Elsevier-North Holland, Amsterdam

Schumpeter JA (1942) Capitalism, socialism and democracy. Harper \& Row, New York

Segeren A, Needham B, Groen J (2005) De Markt Doorgrond, een Institutionele Analyse van Grondmarkten in Nederland. Rotterdam/Den Haag: NAi Uitgevers (in Dutch)

Vander Vegt C, Korteweg J, Lieshout R (2006) Amsterdamse Economische Verkenningen. SEO Amsterdam (in Dutch), Amsterdam

Van Oort FG (2007) Spatial and sectoral composition effects of agglomeration economies in the Netherlands. Pap Reg Sci 86(1):5-30

Wallsten SJ (2001) An empirical test of geographical knowledge spillovers using geographic information systems and firm-level data. Reg Sci Urban Econ 31:571-599 